\title{
Use of Structural Equation Modeling in Ecotourism: A Model Proposal
}

\author{
Yaşar Selman Gültekin ${ }^{1}$, Pınar Gültekin², Osman Uzun², Hande Gök ${ }^{2}$ \\ ${ }^{1}$ Departement of Forest Economics, Faculty of Forest, Düzce University \\ ${ }^{2}$ Departement of Landscape Architecture, Faculty of Forest, Düzce University
}

\begin{tabular}{l}
\hline Article Info \\
\hline Article history: \\
Received May $23^{\text {rd }}, 2017$ \\
Revised June $14^{\text {th }}, 2017$ \\
Accepted June $16^{\text {th }}, 2017$ \\
\hline
\end{tabular}

\section{Keyword:}

Structural equation modeling, Analyze methodology, Ecotourism, Stakeholder analysis, Landscape planning

\begin{abstract}
Structural Equation Modeling (SEM) is an effective model improves and test technique which is explain the relationships between variables in mixed hypotheses related to statistical models and provide to test theoretical models as whole. SEM is an analyze technique that combined the multivariate statistical methods which has been used especially to analyze models in social sciences studies, psychology, sociology, education, economics and marketing.

The aim of this study, to provide for researchers introducing the use of structural equation modeling in ecotourism and to explain model specifications in stakeholder analysis. There are given some definitions, evaluations of model fits, model structures, examples from the ecotourism and landscape planning using SEM and ecotourism model proposals from literature related to SEM methodology. In the conclusion section it will be given a model proposal and recommendations using SEM in ecotourism and stakeholder analysis.
\end{abstract}

\section{Corresponding Author:}

Yaşar Selman Gültekin,

Departement of Forest Economics, Faculty of Forestry,

Düzce University,

Orman Fakültesi, Konuralp Yerleşkesi, 81620, Merkez / DÜZCE.

Email: selmangultekin@duzce.edu.tr

\section{Introduction}

Ecotourism is a type of tourism that includes visits to natural areas and special purposes such as landscaping, wildlife, wilderness exploration, observation and living, leaving as little impact on the environment as possible [1]. With the increase of people's education levels and environmental consciousness, travels especially in natural and culturally sensitive areas have been developing rapidly in recent years. These changes in the structure of international tourism demand increase the demand for ecotourism travels [2].

While participating in the activities of ecotourism, they witness the plants and other living things on the one hand, and on the other hand they have the opportunity to establish friendships with local people and to learn about their cultures and traditional life styles. The people of the region protect ecotourism as an inheritance of their natural richness while raising their economic levels with alternative incomes and job opportunities. In an ecotourism-focused planning process, ensuring more effective involvement of stakeholders in ecotourism activities is challenging as an effective resource management [3].

Interest in modeling structural equilibrium for model analysis is increasingly increasing in studies carried out in the field of social sciences. Structural Equation Modeling (SEM) is a method of analysis consisting of a combination of statistical methods that are used in many areas such as psychology, sociology, education, economics and marketing. Structural equilibrium modeling is an effective model testing and development 
technique that can explain the cause-and-effect relationship of variables in mixed hypotheses related to statistical models and allows the theoretical models to be tested as a whole.

The aim of this study is to conduct stakeholder analysis in participatory ecotourism planning, to identify stakeholders' perceptions of ecotourism and their attitudes, and to discuss the feasibility of structural equation modeling as a new approach to the solution of existing problems. The method of "Structural Equation Modeling (SEM)" which is an unused method in ecotourism planning in Turkey will be applied in participatory ecotourism planning and will have an important place in the future to fill the gap in the literature and studies on ecotourism.

\subsection{Ecotourism}

The phenomenon of ecotourism has emerged with the recognition of the potential benefit of people as a result of their curiosity towards nature [4]. According to reference [5], the concept of ecotourism is a concept that comes to the agenda with the concept of sustainability. Ecotourism, which is the basis of conservation of ecological balance, has emerged as a result of sustainable development [6]. Ecotourism is a broader issue than the activities of tourists who are nature and environmentally conscious. Ecotourism is the whole of environmental, economic and social relations [7].

According to [8], ecotourism is based on ecological sustainability approaching environmental and cultural values with a conservative and sensitive approach. According to [9], ecotourism is more than just tourism activity in natural areas. But the lack of a widely accepted definition of ecotourism and the lack of a common definition of features and dimensions that distinguish ecotourism from other types of tourism is the biggest shortcoming in this area [6]. In this respect, ecotourism is a type of tourism that has been described differently by different circles because of its different forms [10]. According to [11], ecotourism is a type of tourism that takes its natural history, including its local cultures. Ecotourists are those who visit natural areas without consuming natural resources and strive to protect this area [6]. According to [12], ecotourism is an educational journey to nature that contributes to the protection of the ecosystem and respects the existence of local people [6]. [13], has introduced a different perspective to ecotourism by identifying ecotourism as recreational activities related to the natural history or natural life of an area such as bird watching, wildlife observation, whale watching, nature photography, plant survey which do not consume natural resources.

The World Tourism Organization (WTO) and the United Nations (UN) Commission for Sustainable Development declared 2002 the "International Year of Ecotourism" and commissioned the WTO on this subject. The World Ecotourism Summit, held in Quebec, Canada, in May 2002, with the participation of 1,100 delegates from 133 countries, attempted to identify a common definition adopted by all countries. Accordingly, ecotourism has been adopted as "an approach or attitude that protects the social and cultural integrity of the earth while assisting the economic development of the local people, securing the sustainability of the natural resources of the earth" [1]. According to this definition, the most important feature distinguishing ecotourism from other activities based on nature is the ecological sustainability and the aim of acquiring experiences based on education and learning [14].

The concept of ecotourism is concerned with the fact that the actual travel is helping to protect and develop the areas visited. Because ecotourism has a wide variety of elements, it is necessary to understand its structure first [2]. In order to ensure long-term sustainability of ecotourism, it is necessary to take into consideration the basic elements of the structure of this tourism route (Figure 1).

The work and thought partnership of local people, decision-makers, private sector, NGO's and scientists, indispensable stakeholders of ecotourism planning, is a process that can be applied and facilitated. 


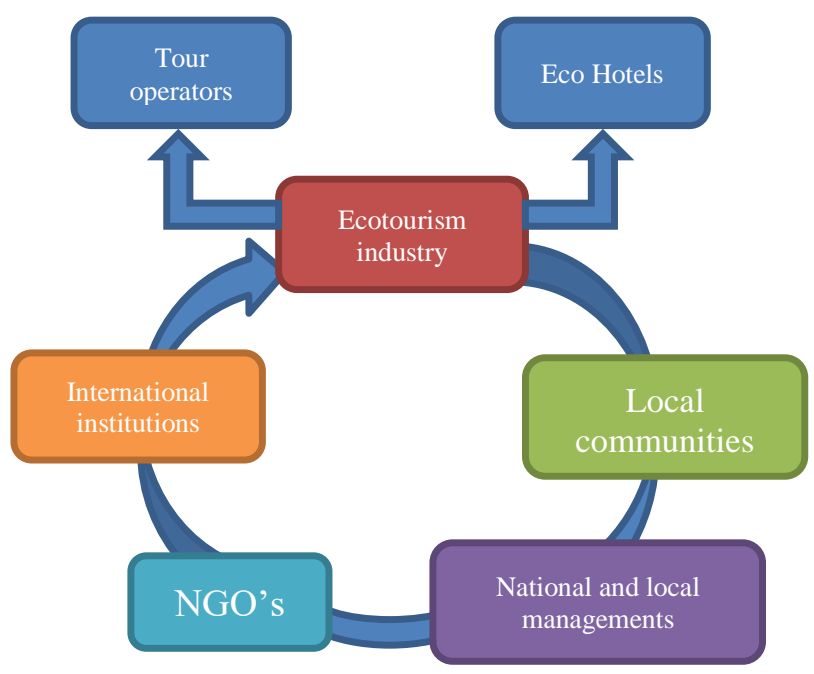

Figure 1. Basic elements of ecotourism [2]

\subsection{Structural Equation Modelling}

Structural Equation Modeling (SEM) is a method of analyzing the use of many fields such as psychology, sociology, education, economics and marketing in recent years and it is composed of multivariate statistical methods [15] [16]. It is possible to come across many studies using SEM in the field of tourism abroad [17] [18] [19] [20]. It can be said that the use of SEM is very limited in the field of ecotourism planning, with many studies made in different branches of science in our country by using SEM [21] [15] [22] [23]. For this reason, it is possible to say that SEM is being used as a new method in the field of ecotourism in our country. SEM is basically based on the researcher's thoughts about a research topic by testing a model of inter-variable relationships that existed before the research is done with the help of the data obtained in the research result. The most significant difference between methods such as variance analysis (ANOVA), multivariate analysis of variance (MANOVA), factor analysis (FA), regression analysis, which are the most used statistical methods in SEM researches [22]. The main objective of the SEM is to explain the interdependency relationship pattern between the one or more observed variables and the implicit non-observable sets of structures [15] [24].

It is stated that the three main components of the structural equation models (SEM) are historical development [24]. These components are path analysis, conceptual synthesis of structural models and measurement models, and finally general estimation processes. Historical development of SEM should be addressed through some statistical concepts on a historical level. These analyzes are regression analysis, path analysis, confirmatory factor analysis (CFA) and finally SEM [26] [23].

The concept of confirmatory factor analysis (CFA) emerged in the 1950s. Karl Jöreskog developed the DFA in 1960 with his theoretical studies of whether or not the data set of a defined structure could be tested [25]. FA is used to construct measurement instruments whereas CFA is used to test the existence of theoretical structures [23].

SEM is mainly a general statistical methodology [27]. SEM uses road diagrams to show default models for causal relationships. Structural equation modeling was first recognized as "JKW" models because it was developed by Karl Jöreskog, Keesling and Wiley. It was later used as "Linear Structural Equation Models" with the development of the LISREL (Linear Structural Relations) program [28]. [29] states that it would be better to call it "Factor Analytical Structural Equation Models" because SEM is based on FA. However, only the SEM concept has been used in recent years due to the use of nonlinear structural equality models [26] [23].

The most general form is a structural equation model, the measurement model and the structural model are two parts. The measurement model specifies how the hidden variables or theoretical structures are related to the observed variables and how they are represented. The structural model identifies the causal relationships between hidden variables and describes causal effects [21] (Figure 2). 


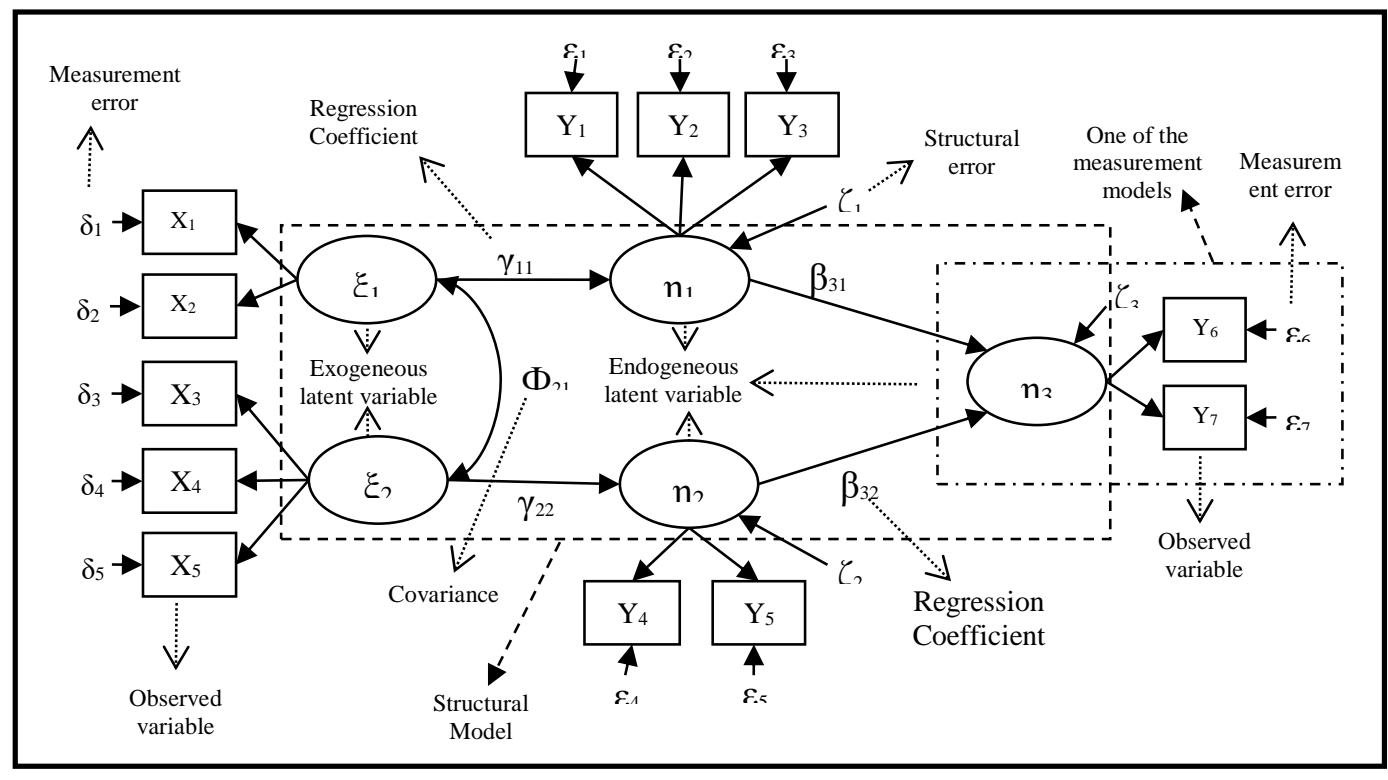

Figure 2. Structural Equation model [30] [22]

When the model is tested in SEM, many different criteria are used in evaluating the conformity of the created model. These measures are called goodness of fit indexes. There are a number of statistical functions that this goodness of fit index has. Similarity ratios between chi-square statistics $\left(\chi^{2}\right)$, Root-Mean-Square Error Approximation (RMSEA), Goodness-of-Fit Index (GFI) and Adjusted Goodness-of-Fit Index [28].

Other fit measures of SEM include Parsimony Normed Fit Index (PFI), Parsimany Goondness of Fit Index (CFI), Comparative Fit Index (CFI), Incremental Fit Index (IFI), Relative Fit Index (RFI) [31]. Researchers using LISREL often use GFI, AGFI, RMSEA, CFI, and NNFI criteria as well as chi-square values in their studies [21] [32]. In the AMOS analysis, the AIK (Akaike Information Criterion), CAIC (Consistent Akaike Information Criterion) and ECVI (Expected Cross Validation Index) model comparison indexes are used in addition to these criteria [33]. Table 1 summarizes the most commonly used metrics for evaluating the suitability of the SEM and the data for these metrics.

Tablo 1. Evaluation of SEM's Suitability [15] [31] [33].

\begin{tabular}{|c|c|c|}
\hline Fit Indexes & Good fit & Acceptable fit \\
\hline $\begin{array}{l}\text { General Model Fit } \\
\chi^{2} \\
\left(\chi^{2} / s d\right)\end{array}$ & $\begin{array}{l}0 \leq \chi^{2} \leq 2 s d \\
0 \leq \chi^{2} / s d \leq 3\end{array}$ & $\begin{array}{l}2 s d \leq \chi^{2} \leq 3 s d \\
3 \leq \chi^{2} / s d \leq 4-5\end{array}$ \\
\hline $\begin{array}{l}\text { Comparative Fit Indexes } \\
\text { NFI } \\
\text { NNFI } \\
\text { IFI } \\
\text { CFI } \\
\text { RMSEA } \\
\end{array}$ & $\begin{array}{l}\geq 0,95 \\
\geq 0,95 \\
\geq 0,95 \\
\geq 0,97 \\
\leq 0,05\end{array}$ & $\begin{array}{c}0,94-0,90 \\
0,94-0,90 \\
0,94-0,90 \\
\geq 0,95 \\
0,06-0,08\end{array}$ \\
\hline $\begin{array}{l}\text { Absolute Fit Indexes } \\
\text { GFI } \\
\text { AGFI }\end{array}$ & $\begin{array}{l}\geq 0,90 \\
\geq 0,90\end{array}$ & $\begin{array}{l}0,89-0,85 \\
0,89-0,85\end{array}$ \\
\hline $\begin{array}{l}\text { Conservative Fit Indexes } \\
\text { PNFI } \\
\text { PGFI }\end{array}$ & $\begin{array}{l}\geq 0,95 \\
\geq 0,95\end{array}$ & - \\
\hline $\begin{array}{l}\text { Root Mean Based Fit Indexes } \\
\text { RMR }\end{array}$ & $\leq 0,05$ & $0,06-0,08$ \\
\hline $\begin{array}{l}\text { Model Comparison Fit Indexes } \\
\text { AIC } \\
\text { CAIC } \\
\text { ECVI }\end{array}$ & & $\begin{array}{l}\text { Smaller values than the compared model } \\
\text { Smaller values than the compared model } \\
\text { Smaller values than the compared model }\end{array}$ \\
\hline
\end{tabular}

\section{Materials and Methods}

The data obtained by scanning the work material on ecotourism and SEM studies are the theoretical models that can be used in tourism and ecotourism studies. SEM methodology is used in analyzing the views, thoughts, perceptions, attitudes and perspectives of the interest groups. SEM can be used as an analysis tool in 
this regard, given that the views of many interest groups need to be analyzed in ecotourism planning. SEM is used in some studies on tourism and ecotourism activities [34] [35] [36] [37] [38] [39] [40] [41] [42]. From this point, it is possible to transform the factors obtained from studies related to ecotourism through SEM into a theoretical model.

\section{Results and Discussuion}

When we look at the work done in the field of ecotourism in Turkey, it is seen that interest groups' perception about perception attitudes takes place [43] [44]. Factors that are effective in the ecotourism perception are the variables regarding the obstacles in front of ecotourism activities, attractiveness of ecotourism resources, resource development and management strategies.

In order to analyze the stakeholders of ecotourism planning by using SEM, the ecotourism perception (EP) model which is theoretically developed, the obstacle in front of the application of ecotourism activities (OFAE), the degree of attraction of ecotourism resources (DAER), resource development (RD) and management strategies (MS). According to this, studies related to the subject can be examined and the Ecotourism Perception Measurement Model (Research Model) can be created as in Figure 3.

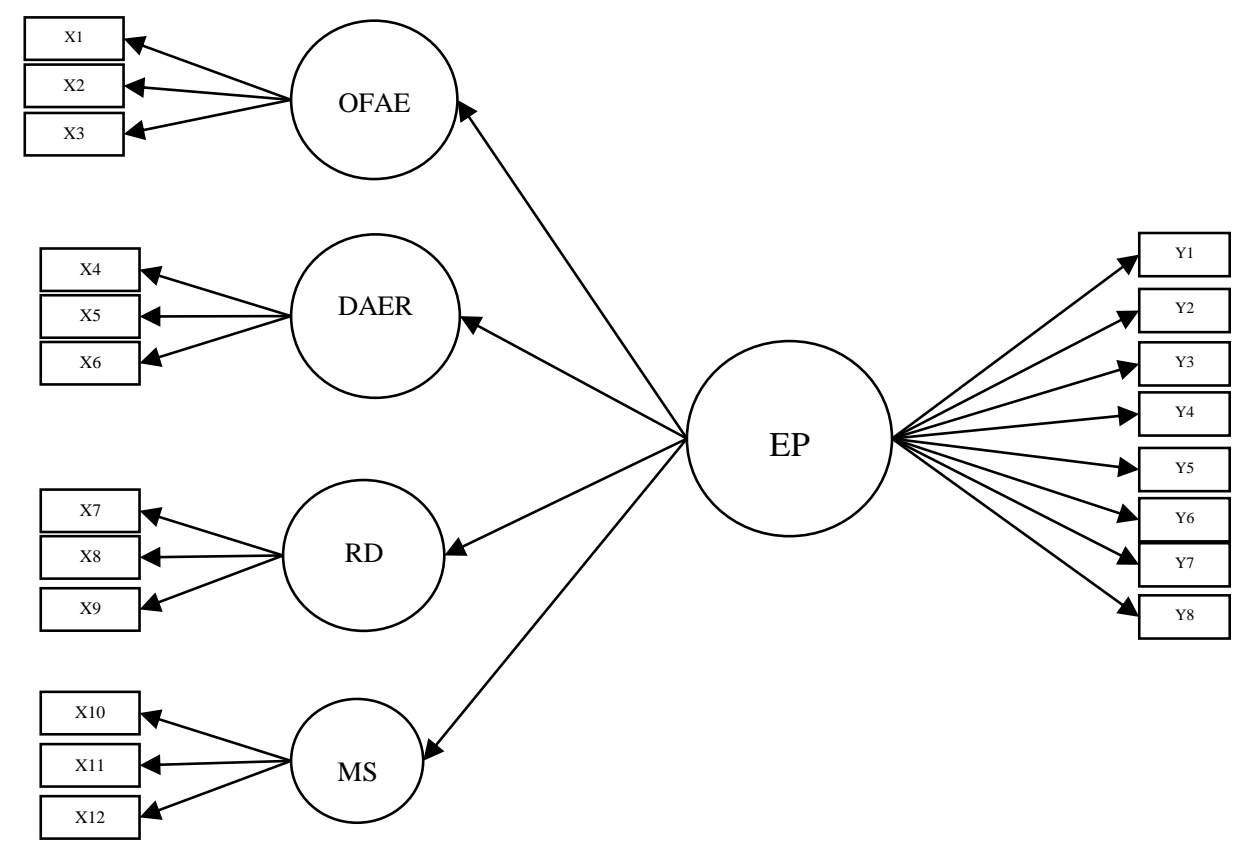

Figure 3. Theoretical research model of ecotourism perception

\section{Conclusion}

It is seen that SEM is limited (10-20\%) when it is used in the world literature from studies done in the field of social sciences [22]. This rate is much lower in our country. In recent years, SEM has been used in scientific fields such as statistics, economics, business, marketing, psychology, sociology in national articles and reports [21]. Since the use of SEM in ecotourism is very limited in Turkey, the use of SEM in solving socioeconomic problems and the continuing increase in such studies can provide significant contributions to the use of SEM in ecotourism and especially in solving socio-economic problems [45].

With participatory ecotourism planning using SEM methodology, it will be possible to conduct scientific studies to develop the local people in place and to sustain the development by evaluating local potential. It will also be possible to obtain guidance on how the ecotourism sector should develop with different stakeholders in different land use policies and how it is likely to develop in future years.

It is possible to use SEM as a method for solving problems related to ecotourism management. However, in the works to be done about SEM, the establishment of measurement and structural models requires a theoretical and statistical infrastructure. If this precondition is met, healthy results will be obtained from the work to be done. 


\section{Acknowledgment}

This study was supported by BAP-2015.02.01.307 numbered Scientific Research Project of Duzce University.

\section{References}

[1]. Koçan N., "Mudurnu (Bolu) ve yakın çevresi peyzaj özelliklerinin ekoturizm kapsamında irdelenmesi", Gümüşhane Üniversitesi Fen Bilimleri Enstitüsü Dergisi GÜFBED/GUSTIJ, 1 (1), 67-78,- 2011.

[2]. Demir C. ve Çevirgen A., "Ekoturizm Yönetimi (1. Basım)”, Ankara: Nobel Yayın Dağıtım, 2006.

[3]. Yeni, E., Gürleyen Kuru, F.,Gülnar, Ö, Örmeci, S., Özerhan, Y., "Zonguldak Natural Tourism Development Plan", Ministry of Forestry and Water Affair, Directorate of Protection of Nature and National Parks. 10 th. Region Sinop, 2013.

[4]. Kılıç N., "Bolu-Göynük ve yakın çevresi doğal ve kültürel kaynaklarının ekoturizm açısından değerlendirilmesi”, Doktora Tezi, A.Ü. Fen Bilimleri Enstitüsü, Ankara, 2006.

[5]. Türker N., Çetinkaya A., "Bat1 Karadeniz bölümü ekoturizm potansiyeli”, Detay Yayınc1lık, 2009.

[6]. Gültekin P., "Düzce Uğursuyu ve Aksu Havzaları ekoturizm potansiyelinin belirlenmesi ve peyzaj yönetimi”, Yüksek Lisans Tezi, Düzce Üniversitesi Fen Bilimleri Enstitüsü, Düzce, 2010.

[7]. Ahipaşaoğlu S., Çeltek E., "Kırsal Turizm”, Gazi Kitabevi, Ankara, 2006.

[8]. Beeton S., "Ecotourism: A Practical Guide for Rural Communities", Land links Press, Australia, 1998.

[9]. Ross, S., Wall, G., "Ecotourism: Towards Congruence Between Theory And Practice", Tourism Management, 20 (1), 123-132, 1999.

[10]. Steele, P., "Ecotourism: an economic analysis", Journal of Sustainable Tourism, 3(1), 29-44, 1995.

[11]. Ziffer K., "Ecotourism: The Uneasy Alliance", Conservation international, Ernst and Young, Washington DC., 1989.

[12]. Wight, P., A. “Ecotourism: Ethics or Eco-Sell?", Journal of Travel Research, 31 (3): 3-9, 1993.

[13]. Hvenegaad G., "Ecotourism: A Status Report and Conceptual Framework", The Journal of Tourism Studies, 5,2, 24-35, 1994.

[14]. Rodger K., Moore S A., Newsome D., "Wildlife Tours in Australia: Characteristics, The Place of Science and Sustainable Tourism", 15 (2), 160-178, 2007.

[15]. Yılmaz, V., Çelik, H.E., "Bankacılık Sektöründe Müşteri Memnuniyeti ve Bankaya Bağlılık Arasındaki İlişkinin Yapısal Eşitlik Modelleriyle Araştırılması", VII. Ulusal Ekonometri ve İstatistik Sempozyumu, 26-27 Mayis 2005, İstanbul.

[16]. Yılmaz, V., Çelik, H. E., "Lirsel ile Yapısal Eşitlik Modellemesi - I”, Pegem Akademi, s.186, 2009.

[17]. Malaeb, Z.A., "Using Structural Equation Modeling to Investigate Relationships Among Ecological Variables", Environmental and Ecological Statistics, Vol. 7, pp. 93-111, 2000.

[18]. Parkins, J.R., Stedman, R.C. , Beckley, T.M., "Forest sector dependence and community well-being: A structural equation model for new Brunswick and British Columbia", Rural Sociology, 1549-0831, 2003, 68 (4) $554-572$.

[19]. Grace, J.B., "Structural Equation Modelling and Natural Systems", ISBN: 9780521837422, Cambridge University Press, New York, 2006.

[20]. Jonsson, M., Wardle, D., "Structural Equation Modelling Reveals Plant community Drivers of Carbon Storage in Boreal Forest Ecosystems", Biology Letters, Royal Society Publishing, Vol. 6, pp. 116-119, 2010 .

[21]. Yılmaz, V., "LISREL ile Yapısal Eşitlik Modelleri: Tüketici Şikâyetlerine Uygulanması", Anadolu Üniversitesi Sosyal Bilimler Dergisi, cilt: 4, no.1, ss.77-90, 2004.

[22]. Ayyıldız , H., Cengiz, E., "Pazarlama Modellerinin Testinde Kullanılabilecek Yapısal Eşitlik Modeli (YEM) Üzerine Kavramsal Bir İnceleme", Süleyman Demirel Üniversitesi, İktisadi ve İdari Bilimler Fakültesi, Y. 2006, C. 11, S.1, s. 63-84.

[23]. Akıncı Deniz, E., "Yapısal Eşitlik Modellerinde Bilgi Kriterleri”, Mimar Sinan Güzel Sanatlar Üniversitesi, Fen Bilimleri Enstitüsü, İstatistik Anabilim Dalı, Yayınlanmamış Doktora Tezi, İstanbul, 2007. 
[24]. Hoyle, R.H., "Handbook of structural equation modeling", The Guilford Press, United States of America, 2012.

[25]. Bollen, K.A., "Structural equations with latent variables”, John Wiley \& Sons, USA, 1989.

[26]. Schumacker, R.E., Lomax, R.G., “A Beginner's Guide to Structural Equation Modeling”, Second Edition, Mahwah, NJ: Lawrence Erlbaum Associates, 2004, 498 p.

[27]. Kline, R.B., "Principles and practices of structural equation modeling", The Guilford Press, New York, USA, 2011.

[28]. Jöreskog, K. Sörbom, D.,” LISREL 8: User's Reference Guide”, Scientific Software International Inc., 2001.

[29]. Bentler, P.M., "EQS 6 structural equations program manual”, Multivariate Software Inc., Encino, CA, 2006.

[30]. Rigdon, E., "The Form of Structural Equation Models", Last updated: April 11, 1996, http://www.gsu.edu/ mkteer/sem2.html, (Access date: 07.02.2012), 1996.

[31]. Şimşek, Ö. F., "Yapısal Eşitlik Modellemesine Giriş (Temel İlkeler ve LISREL Uygulamaları)”, ISBN: 9944-495-07-7, s. 224, Ekinoks, Ankara, 2007.

[32]. Hu, L.T. , Bentler, P.M., "Cutoff criteria for fit indexes in covariance structure analysis: Conventional criteria versus new alternatives", Structural Equation Modeling-a Multidisciplinary Journal, 1070-5511, 10.1080/10705519909540118, 1999, 6 (1) 1-55.

[33]. Meydan, C. H., Şeşen, H., "Yapısal Eşitlik Modellemesi (AMOS Uygulamaları)”, ISBN: 978-605-543701-5, Detay Yayınc1lık, Ankara, 2011.

[34]. Untachai, S., "Modeling Residents' Perceptions on Ecotourism in Upper Northeast, Thailand", In Kerpitak, C., Heuer, and K., Benabdelhafid (Eds.), International Journal of Business Tourism Applied Sciences (pp. 6-19). Bangkok, Suan Dusit Rajabhat University, 2015.

[35]. Ko, D., Stewart, W. P., “A structural equation model of residents' attitudes for tourism developments", Tourism Management, (23): 521-530, 2002.

[36]. Gursoy, D., Jurowski, C., Uysal, M., "Resident Attitudes A Structural Modeling Approach", Annals of Tourism Research, 2002, Vol. 29, No. 1, pp. 79-105.

[37]. Meng, F., "An Examination of Destination Competitiveness from the Tourists' Perspective: The Relationship between Quality of Tourism Experience and Perceived Destination Competitiveness", Doctoral Thesis, Faculty of the Virginia Polytechnic Institute and State University, 224 p., Virginia, 2006.

[38]. Lee, T. H., "An ecotourism behavioral model of national forest recreation areas in Taiwan", International Forestry Review, 2007, Vol. 9, (3): 771-785.

[39]. Chaitip, P., Chaiboonsri, C., Kovács, S., Balogh, P., "A Structural Equation Model: Greece's Tourism Demand for Tourist Destination", Applied Studies in Agribusiness and Commerce, 2008.

[40]. Li, C., "Modeling Forest Recreation Visitors: A Multi-Cultural Marketing Perspective", Paper presented at Conference on Sustainable Forest Management and Carbon Sequestration in Taiwan and Japan. Huisun Forest Station, Experimental Forest Administration, National Chung Hsing University, Taiwan, 2007.

[41]. Zhang, H., Lei, S. L., "A structural model of residents' intention to participate in ecotourism: The case of a wetland community", Tourism Management, 2012, (33): 916-925.

[42]. Ven, S., "Host Residents' Attitude toward Community-based Ecotourism: Empirical Study in Southwestern Cambodia", Journal of Tourism \& Hospitality, 2015, (4): 1, 2015.

[43]. Gültekin, P., Gültekin, Y.S., Uzun, O., "Düzce Uğursuyu ve Aksu Havzalarında Katılımcı Ekoturizm Alg1 Ölçeğinin Geliştirilmesi”, Peyzaj Mimarlığı V. Kongresi, 14-17 Kasım 2013, 904-921, Adana.

[44]. Gültekin, P., Gültekin, Y.S., Uzun, O., "Katılımcı Planlamada Yerel Halk Ekoturizm İlişkisi: Düzce Aydınpınar Köyü Örneği”, III. Uluslararası Odundışı Orman Ürünleri Sempozyumu, 658-671, Kahramanmaraş, 2014.

[45]. Kayacan, B., Gültekin, Y.S., "Use of Structural Equation Modeling in Solving Socioeconomic Problems in Forestry”, III. Ormancllikta Sosyo-ekonomik Sorunlar Kongresi, İstanbul, 2012. 